\title{
Reparação e desamparo: o exercício da justiça através das notificaçôes (Mariana, Minas Gerais, 1711-1888)
}

\author{
Álvaro de Araujo Antunes \\ Universidade Federal de Ouro Preto \\ Ouro Preto, MG, Brasil \\ alvoantunes@gmail.com \\ Marco Antonio Silveira \\ Universidade Federal de Ouro Preto \\ Ouro Preto, MG, Brasil \\ mantoniosilveira@yahoo.com.br
}

\section{RESUMO}

Este artigo visa apresentar alguns resultados derivados da pesquisa de 783 autos de notificação, custodiados pelo Arquivo Histórico da Casa Setecentista (AHCS), em Mariana (MG). Os dados trabalhados, atinentes ao período de 1711 a 1888, foram obtidos através do uso de variáveis estabelecidas numa ficha de coleta em formato eletrônico. Através dos resultados já obtidos, é possível apontar hipóteses sobre o funcionamento da Justiça no termo de Mariana.

Palavras-chave: notificaçôes; Minas Gerais; Justiça.

\begin{abstract}
This paper aims to present some results derived from a research on 783 notification acts that are kept by Arquivo Histórico da Casa Setecentista, in Mariana, Minas Gerais. The data, referring to the period 1711-1888, were obtained through the adoption of variables established in an electronic form. Through the results already reached, it is possible to point out some hypotheses about the inner workings of Justice in the Mariana region.
\end{abstract}

Keywords: notifications; Minas Gerais; Justice. 
O problema da institucionalização da sociedade mineira tem sido discutido com afinco nos últimos anos. Embora antiga, a preocupaçáo com os modos pelos quais os costumes e as instituiçóes - especialmente as estatais - se fixaram em Minas ganhou novo alento com o impacto da obra de António Manuel Hespanha no Brasil. Hespanha, movido pelo objetivo de compreender a especificidade do Estado luso do Antigo Regime, esquadrinhou o território do Reino avaliando em que medida, no século XVII, determinados dispositivos de governo eram capazes de promover a monopolizaçáo dos poderes nas mãos da Coroa. Essa "arqueologia" empreendida pelo autor, como se sabe, ratificou a ideia de que seria anacrônico falar em centralização ou em absolutismo para o período, dadas as limitaçóes financeiras e do aparato administrativo do Estado. Nesse sentido, estratégias políticas marcadas pela negociação com forças concorrentes e com poderosos locais, definidoras de uma doutrina corporativa e prudencial do poder, teriam se implementado como a forma mais adequada e eficaz de legitimar a presença e a atuação da Coroa. ${ }^{1}$ A representação do Reino como corpo místico corresponderia, assim, a um conjunto de práticas capazes de, pelo menos parcialmente, domesticar os poderes concorrentes por meio de táticas de cooptaçáo e da produçáo de uma identidade comum.

O modelo explicativo elaborado por Hespanha tem sido largamente apropriado pela historiografia brasileira dedicada ao estudo da colonizaçáo da América portuguesa. Se a Coroa encontrava tamanha dificuldade para se impor sobre o próprio território luso, o que não dizer das extensas áreas que compreendiam o Império? O conjunto de doutrinas e práticas conformadoras do modelo corporativo, mais do que explicar o funcionamento do Estado na Europa do Antigo Regime, passou a ser adotado como chave para o entendimento de como os portugueses conseguiram articular e manter um império tão vasto, a despeito das limitaçôes técnicas da época. ${ }^{2}$ Tais reflexôes tornaram ainda mais complexos os debates sobre a natureza das relaçôes que articulavam metrópole e colônia. Ao esforço historiográfico, incitado havia décadas, de caracterizar os mecanismos administrativos e econômicos de exploraçáo colonial, bem como de apreciar seu alcance e sua eficácia, somaram-se as análises sobre a existência de vínculos de interesse mantidos entre partes diversas do Império português e sobre as estratégias políticas e ideológicas que, através da cooptação e da produçáo de identidades imperiais, repunham constantemente a autoridade da Coroa. ${ }^{3}$

A apropriação do trabalho de Hespanha nos estudos sobre a América portuguesa não tem ocorrido sem problemas. Aventou-se que o foco sobre as identidades imperiais, articuladas em torno de disposiçóes políticas típicas de uma estrutura corporativa e de Antigo Regime, poderia implicar, no limite, a secundarizaçáo da especificidade dos contextos locais e dos conflitos entre a metrópole portuguesa e suas colônias. Nesse sentido, o esforço de se salientar a emergência de estratégias de negociação entre os diversos níveis de poder tenderia a obliterar o papel ordenador do Estado, bem como o impacto da escravidáo e da transferência de recursos para a Europa. Segundo essa perspectiva, a distorçáo seria ainda mais notável no século XVIII, quando a América portuguesa teria assistido à imposição, mesmo que oscilante, de estruturas e mecanismos de controle da exploração aurífera. ${ }^{4}$

${ }^{1}$ HESPANHA, António Manuel. As vésperas do Leviathan. Coimbra: Almedina, 1994. Na mesma linha, CARDIM,
Pedro. Cortes e cultura política no Portugal do Antigo Regime. Lisboa: Cosmos, 1998; "Administração" e "governo": uma
reflexáo sobre o vocabulário do Antigo Regime. In: BICALHO, Maria Fernanda; FERLINI, Vera Lúcia Amaral (Org.).
Modos de governar. Sáo Paulo: Alameda, 2005. p. 45-68. Numa perspectiva parcialmente distinta e voltada para o século
XVIII, MONTEIRO, Nuno Gonçalo. Elites e poder. Lisboa: ICS, 2003.
${ }^{2}$ Por exemplo, BICALHO, Maria Fernanda; FERLINI, Vera Lúcia Amaral (Org.). Modos de governar, op. cit.
${ }^{3}$ PRADO JR., Caio. Formaçáo do Brasil contemporâneo. 12. ed. São Paulo: Brasiliense, 1972; NOVAIS, Fernando Antônio.
Portugal e Brasil na crise do Antigo Sistema Colonial. 4. ed. São Paulo: Hucitec, 1986; MAXWELL, Kenneth. A devassa
da devassa. 3. ed. Rio de Janeiro: Paz e Terra, 1985; ALENCASTRO, Luiz Felipe de. O trato dos viventes. São Paulo:
Companhia das Letras, 2000; FRAGOSO, João; FLORENTINO, Manolo. O arcaísmo como projeto. Rio de Janeiro:
Civilização Brasileira, 2001; e FURTADO, Júnia Ferreira. Homens de negócio. São Paulo: Hucitec, 1999.
${ }^{4}$ Antonio Manuel Hespanha tratará de críticas dessa natureza ao comentar as observaçóes tecidas por Laura de Mello e 
No que diz respeito ao caso de Minas Gerais, as contribuiçôes trazidas por Hespanha se inseriram num contexto mais amplo de discussão sobre o caráter do Estado e da sociedade que se constituíram no decorrer do século XVIII. A preocupação com a temática antecede a recepção do historiador português, remetendo aos próprios governantes da capitania, que, no século XVIII, apresentaram um inventário de preocupaçôes políticas relativas a essa importante regiáo do império. De uma forma geral, dois elementos sempre se destacaram nos estudos concernentes à colonização de Minas: sua importância na produção de formas urbanas e estatais na América portuguesa, de um lado, e, de outro, a extensão das atitudes rebeldes e contestatórias. Focando a criação de vilas, a expansão institucional, a vinda de funcionários régios e o peso do aparelho fiscal, diversos historiadores sublinharam a força dos expedientes burocráticos na sociedade mineira, sem, no entanto, perder de vista o clima de instabilidade, revolta e tensão que a perpassava. ${ }^{5}$

$\mathrm{Na}$ historiografia dedicada às Minas foram muitas as pesquisas que destacaram a instabilidade, o conflito e a rebeldia como aspectos cruciais da vida social. O artigo clássico que Sérgio Buarque de Holanda publicou na década de 1960 caracterizou as Minas Gerais setecentistas como uma sociedade em "ebulição íntima", uma "estrutura movediça que se desmancha, em partes, e se recompóe continuamente, ao sabor das contingências imprevisíveis" - enunciado que caberia não apenas às primeiras décadas do século XVIII, mas ao conjunto da centúria, a despeito de, segundo o autor, a "aparência de estratificação" e a "ordenação forçada" terem com o tempo substituído o "tumulto inicial".

$\mathrm{Na}$ década seguinte, retomando a obra de Sérgio Buarque e as reflexôes da historiografia marxista dedicada ao estudo da colonizaçáo do Brasil, Laura de Mello e Souza descreveu as Minas como uma sociedade definida pela instabilidade e pela tensão social, expressas na existência de uma ameaçadora camada de marginalizados. ${ }^{7}$ Mais recentemente, os trabalhos de Carla Anastasia e Adriana Romeiro constituem outros exemplos de investigação historiográfica que tende a descrever a sociedade mineira setecentista destacando seus elementos de contestação e subversão. A despeito das diferenças de enfoque, para as autoras, cujos estudos se dedicam fundamentalmente à primeira metade da centúria, as diversas formas de usurpaçáo das instituiçóes e dos dispositivos estatais por parte dos poderosos locais geravam nas Minas um quadro permeado pela imprevisibilidade social. ${ }^{8}$

As reflexôes de Hespanha levaram à retomada de alguns dos temas já amplamente discutidos pelos historiadores voltados ao estudo das Minas, estimulando ainda o aprofundamento de questóes tais como o papel das câmaras municipais na negociação dos interesses locais, o desempenho de magistra-

Souza. SOUZA, Laura de Melo. O sol e a sombra: política e administração do Império português no século XVIII. São Paulo: Companhia das Letras, 2006. HESPANHA, Antonio Manuel. Depois do Leviatá. Almanack Brasiliense, n. 5, maio 2007.

${ }^{5}$ Por exemplo, e apesar das diferenças que os separam, IGLÉSIAS, Francisco. Minas e a imposição do Estado no Brasil. Revista de História, Sáo Paulo, n. 100, p. 257-273, out./dez. 1974; SOUZA, Laura de Mello e. Desclassificados do ouro. 2. ed. Rio de Janeiro: Graal, 1986; Norma e conflito. São Paulo; Belo Horizonte: Companhia das Letras; Ed. da UFMG, 1999; BOSCHI, Caio César. Os leigos e o poder. São Paulo: Ática, 1986; FURTADO, Júnia Ferreira. O Livro da Capa Verde. São Paulo: Annablume, 1996; FIGUEIREDO, Luciano Raposo. Barrocas famílias. São Paulo: Companhia das Letras, 1997.

${ }^{6}$ HOLANDA, Sérgio Buarque de. Metais e pedras preciosas. In: __ (Ed.). A época colonial — administração, economia, sociedade. Rio de Janeiro: Difel, 1982. v. II, p. 259-310. (História geral da civilização brasileira).

7 SOUZA, Laura de Mello e. Desclassificados do ouro. Sobre a caracterização das Minas como uma sociedade perpassada pela instabilidade. Ver também SILVEIRA, Marco Antonio. O universo do indistinto. São Paulo: Hucitec, 1997.

${ }^{8}$ ANASTASIA, Carla Maria Junho. Vassalos rebeldes. Belo Horizonte: C/Arte, 1998; A geografia do crime. Belo Horizonte: Ed. da UFMG, 2005; ROMEIRO, Adriana. Paulistas e emboabas no coração das Minas. Belo Horizonte: Ed. da UFMG, 2008. Também sobre as primeiras décadas de ocupação das Minas, mas numa perspectiva diferente, CAMPOS, Maria Verônica. Governo de mineiros. Tese (doutorado em história) — Universidade de São Paulo, São Paulo, 2002. Sobre o exercício da justiça na capitania de Minas Gerais na segunda metade do XVIII, e especialmente sobre as práticas faccionais dos advogados, ANTUNES, Álvaro de Araújo. Espelho de cem faces. São Paulo; Belo Horizonte: Annablume; PPGH/ UFMG, 2004; ANTUNES, Álvaro de Araújo. Fiat justitia: os advogados e a prática da justiça em Minas Gerais (17501808). Tese (doutorado em história) — Universidade Estadual de Campinas, Campinas, 2005. 
dos e governadores e a incorporação de potentados às estruturas burocráticas. Estudos recentes sobre a Comarca de Vila Rica, por exemplo, têm recuperado o perfil dos agentes jurídicos e administrativos locais em diferentes instâncias, focalizando desde juízes ordinários até oficiais de vintena. ${ }^{9}$ Mesmo os temas mais diretamente ligados ao problema da contestação passaram a ser tratados sob a ótica da doutrina corporativa e da formaçáo de uma identidade imperial. ${ }^{10}$

Nesse contexto, também o tema do desenvolvimento dos mercados regionais tornou-se central nas análises historiográficas. Pesquisas sobre a diversidade produtiva e a multiplicidade dos circuitos comerciais dentro e fora das Minas retomaram e adensaram muitas das proposiçóes formuladas pelo trabalho pioneiro de Mafalda Zemella. ${ }^{11}$ Tais pesquisas levaram os historiadores a refletir mais atentamente a respeito do grau de ordenação e de integração da sociedade mineira setecentista, colocando-se em xeque a tese de que as Minas haviam se caracterizado essencialmente pela instabilidade. À luz das questôes formuladas por Hespanha e por outros estudiosos, tornou-se imperativo, por exemplo, avaliar a existência e a abrangência, já no século XVIII, de um movimento avant la lettre de "interiorização da metrópole", ancorado na integração dos interesses mercantis das Minas com aqueles sediados no Rio de Janeiro e em outras partes do Império português. ${ }^{12}$

Outro aspecto das recentes discussôes está na tendência de superação das barreiras artificiais que têm separado a segunda metade do século XVIII das primeiras décadas do XIX. O tema da interiorização da metrópole já havia suscitado na historiografia mineira um importante estudo sobre as relaçôes entre a formaçáo do setor dedicado ao abastecimento no Sul de Minas e a constituiçáo do grupo liberal moderado no Primeiro Império — abordagem que, com diferenças de enfoque, tem sido retomada mais recentemente. ${ }^{13}$ Consolidaram-se posteriormente investigaçôes que, valendo-se das listas nominativas, entre outros tipos de fonte, possibilitaram caracterizar as Minas oitocentistas como uma sociedade escravista - apesar do peso expressivo da população livre e liberta - e fundada num rol diversificado de atividades econômicas. A hipótese de que à decadência da mineraçáo se seguiu um quadro de irreversível degradação econômica foi definitivamente superada e cedeu lugar à imagem de uma "acomodação evolutiva” calcada principalmente no setor agropecuário - ainda que as controvérsias sobre a nature$\mathrm{za}$ e as causas desses rearranjos permaneçam intensas. ${ }^{14}$

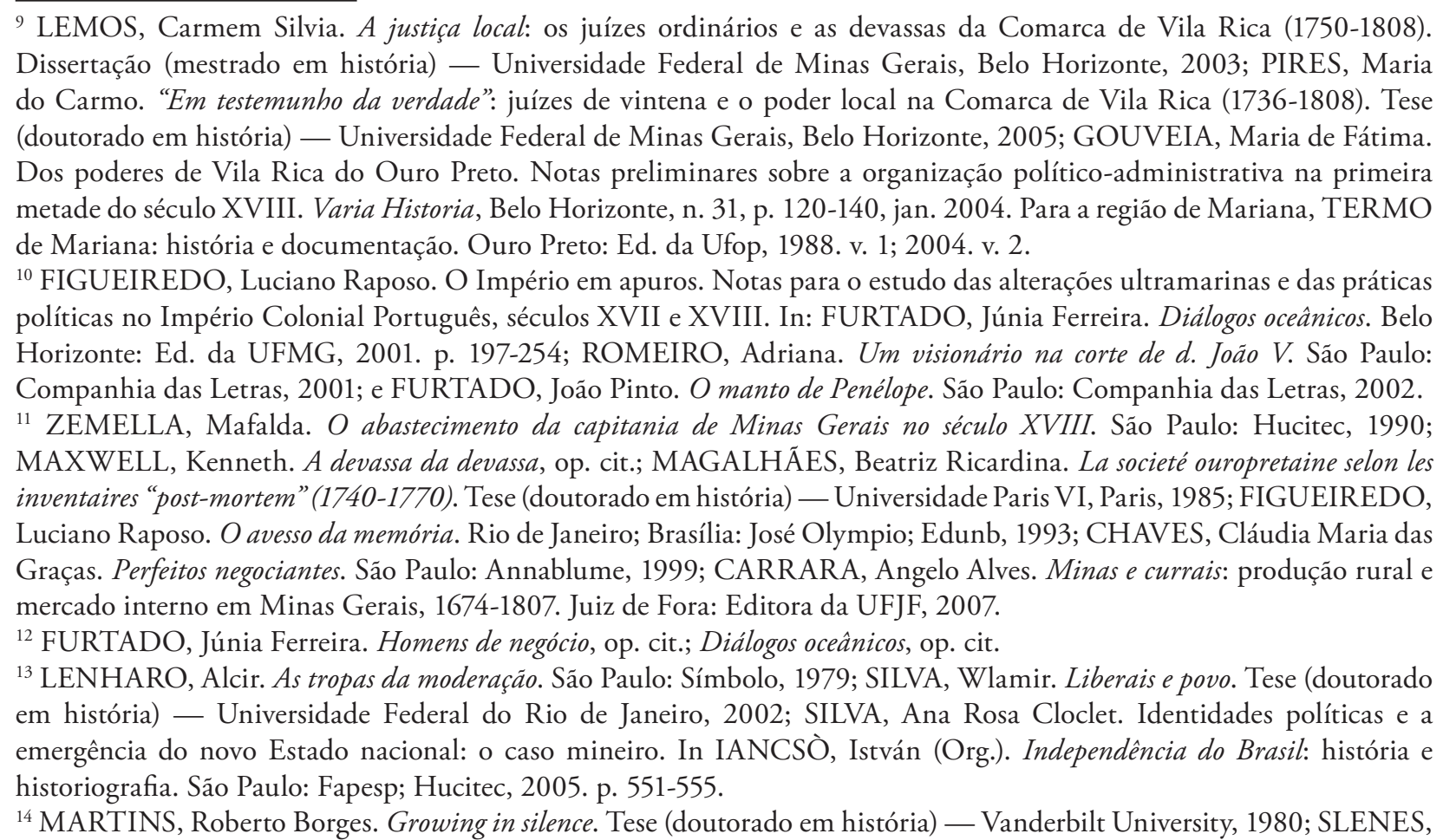


Esse perfil econômico e demográfico que a historiografia traçou para a sociedade mineira do século XIX encontra-se fortemente associado às preocupaçôes com a formação do Estado nacional. Se a chegada da Corte ao Brasil em 1808 implicou a expansão das instituiçôes de justiça típicas do Antigo Regime, após a Independência de 1822, e de modo especial na década de 1830, ocorreram mudanças estruturais significativas articuladas à apropriação das concepçóes liberais e da ideia de constituição. Autoridades do período, como Manuel Inácio de Mello e Souza, presidente da província mineira entre 1831 e 1833, preocuparam-se em criticar, partindo das novas noçôes, o exercício da justiça do período colonial, destacando sua ineficiência, bem como sua incapacidade de resolver conflitos de modo satisfatório em meio às consequências advindas dos embates jurisdicionais, da privatização dos postos, do choque entre diversas fontes legais e do impacto do direito costumeiro. ${ }^{15}$ Críticas dessa natureza resultaram na separação, no âmbito municipal, entre funçôes administrativas e judiciais, deixando as câmaras de responsabilizarem-se pelas últimas. Nesse cenário, foram criados os postos de juiz de paz - que assumia em certa medida deveres anteriormente cabíveis aos juízes de vintenas —, de juiz municipal e, na esfera das comarcas, de juiz de direito. Mais tarde, surgiram os delegados e subdelegados, cargos que estavam no cerne de um debate complexo sobre as relaçóes entre as dimensóes judicial e policial.

Todas essas alteraçóes, além de se apresentarem como tentativas de superar o modelo antigo mediante a consolidação de um paradigma fundado na racionalidade hierárquica e na orientação projetiva do direito positivo, imiscuíram-se também nos embates relativos à maneira pela qual se daria a distribuição dos poderes entre os níveis distrital, municipal, regional e nacional. Nesse sentido, a historiografia buscou entender de que modo se dera a gestaçáo de um projeto conservador calcado em concepçôes centralizadoras do exercício da política e da administração. Ilmar Rohlof de Mattos, por exemplo, discutiu a açáo e os procedimentos saquaremas visando expandir a capacidade regulatória do Estado. ${ }^{16}$ Por sua vez, José Murilo de Carvalho analisou a cúpula do governo imperial apontando suas características e identidades, as quais, para além dos rótulos partidários, diriam respeito ao impacto da formação universitária. Nos termos do autor, "a homogenidade ideológica e de treinamento" adquirida nos bancos da Universidade Coimbra "é que iria reduzir os conflitos intraelite e fornecer a concepção e a capacidade de implementar determinado modelo de dominação política”. ${ }^{17}$ Mais recentemente, no entanto, Miriam Dolhnikoff, investigando o funcionamento de instituições provinciais, colocou em xeque a tese da vitória do modelo centralizador sob o argumento de que a necessidade de constantes negociaçóes entre os diversos níveis de poder resultou na gestação de um pacto de caráter federativo. A autora, assim, destacou o papel das elites na manutenção da ordem através da promoção de constantes rearranjos políticos e institucionais entre o núcleo do governo sediado no Rio de Janeiro e suas bases políticas provinciais. Entre as disposiçōes reguladoras e as forças políticas divergentes, a história da construção do Estado brasileiro teria sido "a história da tensão entre a unidade e a autonomia". ${ }^{18}$

No Brasil, o Estado procurava impor-se por meio do controle territorial e fronteiriço, da aplicaçáo de leis abrangentes, da fixaçáo de impostos e do fortalecimento das estruturas de controle, com destaque para as forças militares e para as estruturas técnico-administrativas. As mobilizaçóes sociais do período, contudo, revelam a outra face de um império amarrado às tradiçôes monárquicas e escravistas, bem

Robert. Os múltiplos de porcos e diamantes: a economia escravista de Minas Gerais no século XIX. Cadernos IFCH, Unicamp, n. 17, 2005; LIBBY, Douglas Cole. Transformação e trabalho em uma economia escravista. São Paulo: Brasiliense, 1988; PAIVA, Clotilde Andrade. População e economia nas Minas Gerais do século XIX. Tese (doutorado em história) Universidade de São Paulo, São Paulo, 1996.

${ }_{15}$ SOUZA, Manuel Inácio de Mello e. A administração da justiça em Minas Gerais (1827). Revista do Arquivo Público Mineiro, v. 3, 1898, p. 55-22.

${ }^{16}$ MATTOS, Ilmar Rohlof de. O tempo saquarema. São Paulo: Hucitec, 1987. p. 183.

${ }^{17}$ CARVALHO, José Murilo de. A construção da ordem. Rio de Janeiro: Campus, 1980. p. 21.

${ }^{18}$ DOLHNIKOFF, Miriam. O pacto imperial. São Paulo: Globo, 2005. p. 11. 
como suscetível à opiniâo pública e às forças políticas centrífugas potencialmente fragmentadoras da unidade nacional. Entre a perspectiva de uma nação brasileira assentada na racionalidade e na autoridade do Estado imperial, de um lado, e, de outro, aquela que valoriza o povo e as elites imersos em forças de dispersão e coesão, a historiografia brasileira buscou problematizar a tessitura entre Estado e nação.

Toda a discussão acerca da formação do Estado nacional tem resultado numa reavaliação do funcionamento das instâncias jurídicas e administrativas durante o Império brasileiro. Pesquisadores de São João del-Rei serviram-se do tratamento quantitativo de fontes cartorárias para dimensionar a eficácia das instâncias judiciais na referida região. Relendo criticamente a bibliografia que compreendeu a atuação dos agentes estatais como submissa aos interesses privados, tais estudiosos têm sugerido que, ao acolherem e mediarem contendas cotidianas, os tribunais viram sua autoridade reforçada pelas camadas pobres ou remediadas. Desse modo, as reformas efetuadas no decorrer do século XIX, geradoras de avanços tanto quantitativos quanto qualitativos, teriam produzido para o período um quadro bastante distinto daquele experimentado nas primeiras décadas dos Setecentos. ${ }^{19}$

Em linhas gerais, pode-se dizer que, nos últimos anos, parte expressiva dos estudos relativos à história de Minas Gerais dos séculos XVIII e XIX pautou-se por um enfoque voltado para a busca de elementos identificados com processos de ordenamento e integração social. Análises sobre a constituição de mercados, o funcionamento da Justiça ou a formação de identidades políticas, embora complexas e variadas, têm muitas vezes apresentado como eixo comum a preocupação de resgatar a importância de estruturas institucionais e costumeiras na organização da vida social. Essa tendência, de um lado, deve-se a certa profissionalização da história no Brasil, fenômeno que implicou o alargamento dos diversos campos de pesquisa, bem como sua sofisticação temática e metodológica. De outro, é o resultado da própria historicidade que caracteriza o trabalho do historiador, uma vez que as profundas mudanças ocorridas no mundo nas décadas de 1980 e 1990 se desdobraram na crítica aos paradigmas vigentes até então. Seja como for, tais contribuições, pelo menos no que diz respeito ao estudo da sociedade mineira, não se apresentam, via de regra, como leituras excludentes ou simplistas. Ao resgatarem aspectos geralmente negligenciados, têm, pelo contrário, apontado para a formulação de modelos explicativos mais complexos e capazes de conjugar elementos de ordenaçáo e de subversão social.

Assim, compreender a natureza e a extensão do arcabouço institucional engendrado em Minas Gerais durante os séculos XVIII e XIX, bem como o significado das diversas formas pelas quais os dispositivos jurídicos e administrativos foram apropriados socialmente, consistem hoje em objetivos cruciais da historiografia. A análise de como a Coroa portuguesa e o Estado brasileiro promoveram a expansão de suas estruturas administrativas cooptando e domesticando os poderosos locais, ou de como estes últimos foram capazes de apropriá-las em benefício de suas próprias estratégias faccionais, é um dos caminhos possíveis de investigação. Outra alternativa, a que se pretende desenvolver aqui, implica avaliar o alcance das estruturas jurídicas junto às camadas intermediárias da população com o intuito de recuperar tanto as tensóes e formas de sociabilidade experimentada por vizinhos e parentes, quanto a dinâmica do funcionamento cotidiano da Justiça. Para a realizaçáo de ambos os objetivos, as notificaçóes têm muito a oferecer.

\section{As notificaçôes como fonte}

Graças às suas peculiaridades e às importantes informaçóes que oferecem, fontes documentais de caráter judicial, tais como processos-crime, inventários e testamentos, revelam-se aparatos decisivos para

${ }^{19}$ VELLASCO, Ivan de Andrade. As seduçôes da ordem. Bauru (SP): Edusc, 2004. 
os historiadores. As notificaçôes, de sua parte, consistiam num instrumento jurídico através do qual um ou mais indivíduos eram citados para comparecer em juízo e responder a uma determinada demanda, queixa ou reclamaçáo. ${ }^{20}$ Nas Minas Gerais dos séculos XVIII e XIX, elas cobrem o extenso período que vai da constituição das primeiras câmaras, em 1711, até o final do período imperial, em 1888, contemplando objetivos variados: dar contas de inventários e tutelas, assumir testamentarias, efetuar despejos de casas e terras, resolver conflitos de vizinhança, concluir obras, coibir invasóes, exibir documentos, fazer entrega de bens, dissolver sociedades, impor a assinatura de termos de bem viver etc. ${ }^{21}$

Cada notificação correspondia a uma série de trâmites padronizados. Normalmente, o notificante apresentava ao juiz uma petição na qual expunha sua demanda ou queixa. O julgador, ao recebê-la, despachava ordenando que se citasse a parte. Atrás da petição, registrando data e local, o oficial responsável informava ter citado o notificado para comparecer ao tribunal. No dia da primeira audiência, o escrivão fazia a autuação, instruindo sobre os dados fundamentais do auto. A partir de então, iniciava-se o procedimento propriamente dito, cuja extensão e complexidade variavam de acordo com a causa em questáo, o empenho das partes envolvidas e a eficiência dos agentes judiciais. Embora em boa parte dos casos a presença do notificado em juízo sanasse a causa de sua citação, em muitos casos a notificação desdobrava-se em litígios mais complexos, assumindo a forma de libelos cíveis ou de outros tipos de processo. De um modo ou de outro, as notificaçôes permitem que se recupere e se sistematize um sem-número de informaçóes relevantes sobre o perfil dos litigantes e o funcionamento da Justiça. Por serem comumente objetivas, elas atraíam um público específico, caracterizado por indivíduos que geralmente almejavam resolver, com alguma celeridade, conflitos familiares e vicinais. Por esse motivo constituem um importante instrumento para a avaliação do alcance e da eficácia dos dispositivos jurídicos instituídos nos períodos colonial e imperial.

Embora todo tipo de procedimento judicial desperte o interesse do pesquisador, as notificaçôes remetem a aspectos ainda pouco estudados pela historiografia. Querelas e devassas têm sido utilizadas pelos historiadores que procuram compreender mais profundamente a natureza das tensóes sociais nas Minas, bem como os atributos da criminalidade. ${ }^{22}$ Contudo, embora contribuam decisivamente para a análise da formação dos costumes, tais investigaçôes criminais, por suas próprias características, tendem a relegar a segundo plano as formas arraigadas de arranjo comunitário. Outras séries documentais trazem dados decisivos sobre algumas dessas formas, mas permanecem limitadas quanto à sua variedade. Inventários e testamentos, por exemplo, ao retratarem momentos específicos da configuraçáo de propriedades e de laços comunitários, são de modo geral insuficientes na recuperação de parte de sua dinâmica e complexidade. ${ }^{23}$ Os libelos cíveis, por sua vez, quando extensos e atinentes a disputas in-

\footnotetext{
${ }^{20} \mathrm{O}$ presente artigo traz alguns dados do projeto "Notificaçóes de Mariana e Ouro Preto (1711-1888): banco de dados e inventário analítico". O projeto recebeu apoio da Fapemig e foi coordenado pelos professores Álvaro de Araujo Antunes e Marco Antonio Silveira. Atualmente, Silveira desenvolve com o apoio do CNPq uma análise das notificaçóes em perspectiva comparada.

${ }^{21}$ Para uma investigação mais profunda sobre as notificações, ver COSTA, Wellington Júnio Guimarães da. As tramas do poder: as notificações e a prática da justiça nas Minas setecentistas. Dissertação (mestrado em história) — Universidade Federal de Ouro Preto, Mariana, 2011.

${ }^{22}$ A querela consistia numa investigação criminal originada pela denúncia de um ou mais ofendidos. Correspondia, na verdade, a uma primeira fase de investigação, baseada na escuta de algumas poucas testemunhas, podendo redundar, em caso de pronúncia, na instauração de um libelo-crime, processo aprofundado no qual o réu seria livrado ou condenado. A devassa, por sua vez, consistia numa investigação criminal que não se originava da denúncia de um ou mais ofendidos, mas, sim, da obrigação ex-oficio que o juiz tinha de conhecer dos casos que lhe eram noticiados. Normalmente, após a escuta de trinta testemunhas, havendo pronunciado, dava-se início ao libelo-crime. Na prática, portanto, querelas e devassas correspondiam à fase de investigação que posteriormente foi atribuída aos delegados de polícia.

${ }^{23}$ Como se sabe, os testamentos implicavam a descrição relativamente sumária dos bens e das vontades de legação de uma determinada pessoa, tendo como fundamento a legislação vigente. Nesse sentido, visavam legalizar a transferência do patrimônio de uma geração a outra por ocasião dos falecimentos. Os inventários, por seu turno, consistiam na listagem e
} 
trincadas, tornam possível a reconstituição verticalizada das comunidades neles envolvidas. ${ }^{24}$ Tendem, porém, a concernir apenas a disputas patrimoniais de maior fôlego. As notificaçôes, assim, parecem preencher uma lacuna analítica na medida em que expressam tanto a variedade dos arranjos comunitários, quanto a dinâmica que permeava os conflitos e sua resolução. Entre esses conflitos, pelo menos no caso de Mariana, merecem ser mencionados os que diziam respeito à posse ou ocupação de imóveis. Em boa medida, a história das disputas cotidianas pela propriedade privada nas Minas ainda está por ser feita.

Neste sentido, foram consultadas e processadas 783 notificaçóes do $1^{\circ}$ e $2^{\circ}$ ofícios, todas sob a guarda do Arquivo Histórico da Casa Setecentistas (AHCS), na cidade de Mariana. As informaçóes obtidas nessa primeira etapa, depois de quantificadas, cruzadas e analisadas, indicam alguns resultados interessantes. Do total de autos, $41,9 \%$ foram gerados no século XVIII, enquanto $57,5 \%$ se referem ao século XIX. A distribuição dos autos por cinco períodos, conforme indicado na tabela 1 , demonstra que sua produção se concentrou nas fases 1751-1808 e 1809-1830, esta última atingindo uma média bastante elevada de notificaçóes por ano quando cotejada com as demais. Há de se destacar que o número de autos para o primeiro período é quase o dobro do estabelecido para os dois últimos. Conquanto a perda de documentos ocorra em decorrência de inúmeros fatores, é comum que, em arquivos cartorários, os mais recentes superem em quantidade os mais antigos. Apesar disso, talvez não seja excessivamente arriscado sugerir, como hipótese, que o conjunto analisado apresenta certa coerência: evoluindo segundo uma curva de produção que atingiu seu pico por volta da época da Independência, teria sofrido, desde então, um forte movimento descendente. Isso se explicaria por dois fatores, pelo menos: por um lado, a expansão das estruturas jurídicas, que, como se sabe, ganhou alento com a transferência da Corte para o Brasil em 1808 e com as tentativas de organização do Estado nacional no Brasil; por outro, os possíveis impactos das mudanças institucionais e legais ocorridas na década de 1830. É possível que as notificaçóes, tendo servido como instrumento relativamente eficaz durante a constituiçáo e a vigência do modelo jurídico administrativo do Antigo Regime, perdessem importância após as reformas que esvaziaram os poderes camarários e locais. Assim, a concentração do uso desse tipo de auto no período 1809-1830 se explicaria pelo vigor da expansáo do antigo modelo antes de seu desmantelamento.

Tabela 1

Distribuiçáo dos autos por períodos e médias anuais

\begin{tabular}{|c|c|c|c|}
\hline Período & № de autos & $\%$ & Média anual \\
\hline $1711-1750$ & 147 & 18,8 & 3,68 \\
\hline $1751-1808$ & 250 & 31,9 & 4,24 \\
\hline $1809-1830$ & 304 & 38,9 & 13,22 \\
\hline $1831-1850$ & 42 & 5,3 & 2,00 \\
\hline $1851-1888$ & 40 & 5,0 & 1,02 \\
\hline $1711-1888$ & 783 & 100,0 & 4,39 \\
\hline
\end{tabular}

Fonte: Notificações (1711-1888), AHCS.

avaliação dos bens de um defunto ou de alguém desprovido da capacidade de administrá-los, visando o cumprimento dos títulos estabelecidos nos testamentos e a distribuição adequada da herança e do patrimônio.

${ }^{24}$ Os libelos cíveis eram açóes centradas em matérias variadas, geralmente de caráter patrimonial. Constituíam-se, em linhas gerais, pela exposição articulada de motivos, feita tanto por autor quanto por réu, pela anexação de documentos, pelas razóes dos advogados das partes e pela sentença final. 
Seja como for, os dados contidos nas notificaçôes mostram-se promissores no que se refere à investigação de como as estruturas de Justiça funcionavam em Minas Gerais. Isso porque permitem avaliar em que medida certos grupos sociais podiam contar com os diversos tribunais na resoluçáo de seus conflitos.

\section{Notificantes e notificados}

A recuperação do perfil social dos grupos que acessavam a Justiça é prejudicada pelo número bastante expressivo de casos de ausência de informação. Qualquer tentativa de dimensionar com mais rigor a condição e a qualidade de notificantes e notificados parece fadada ao fracasso. Não seria adequado atribuir a ausência de informaçáo a qualquer fenômeno social identificado ao silenciamento de categorias, pois o problema abrange não somente o século XIX, mas também o XVIII, período em que o uso generalizado de referências de condiçáo e qualidade é incontestável. A falta de tais informaçôes deriva provavelmente da natureza da fonte: enquanto em certos processos judiciais a descrição de uma testemunha precisava ser mais ou menos completa, visto que suas características interferiam na própria qualificação do depoimento, nas notificaçóes esse procedimento não era previsto, nem essencial.

Ainda assim, foi possível identificar uma pequena quantidade de referências a negros, indígenas, mestiços e forros. Quando justapostas ao fato de as notificações abarcarem proprietários em geral, tais incidências sugerem (e apenas sugerem) que esses casos são exceçôes, pois as notificaçôes foram majoritariamente utilizadas por indivíduos brancos e livres. Porém, ainda que escassa, a referência à condição de indivíduos forros (14) e quartados (7), por exemplo, indica que a mobilidade social teria reflexos no acesso à justiça. Chama a atençáo, também, a presença de alguns carijós (14), dado que deve ser relacionado com o fato de vários dos documentos em questão terem resultado de demandas em áreas de fronteira.

De acordo com a pesquisa, os agentes sociais que mais ocuparam os espaços da justiça durante o período analisado eram do sexo masculino. Os totais contidos na tabela 2 ultrapassam o teto de 783 (número das notificaçóes trabalhadas) porque cada auto poderia envolver mais de um notificante ou notificado. Esses totais seriam ainda maiores se muitas das notificaçôes não se originassem da iniciativa do próprio juízo - daí, aliás, a ocorrência de mais dados sobre o sexo dos notificados (901) do que dos notificantes (576). Contudo, a preponderância masculina é evidente: $84,9 \%$ destes e $79,5 \%$ daqueles.

Tabela 2

Distribuiçáo dos autos de notificação segundo o gênero (termo de Mariana, 1711-1888)

\begin{tabular}{|c|r|r|r|r|r|r|}
\hline G/P & A & B & C & D & E & F \\
\hline \multicolumn{7}{|c|}{ Notificantes } \\
\hline Homem & 136 & 174 & 137 & 26 & 27 & 489 \\
\hline Mulher & 2 & 35 & 35 & 4 & 3 & 87 \\
\hline \multicolumn{7}{|c|}{ Notificados } \\
\hline Homem & 148 & 242 & 298 & 29 & 32 & 716 \\
\hline Mulher & 13 & 44 & 103 & 19 & 09 & 185 \\
\hline
\end{tabular}

Fonte: Notificaçóes (1711-1888), AHCS.

G/P: Gênero/Período

A: 1711-1750; B: 1751-1808; C: 1809-1830; D: 1831-1850; E: 1851-1888; F: 1711-1888. 
Em relação à questão do gênero, vale a pena destacar dois pontos. De um lado, a brusca queda na relação homem/mulher na passagem do primeiro para o segundo período — de 68,0 (136/2) para 4,9 (174/35) entre notificantes e de 11,3 (148/13) para 5,5 (242/44) entre notificados. Tais informaçôes corroboram preconceitos relativos ao papel das mulheres nas sociedades do período, em especial os que marcavam as donas e donzelas com a pecha da exposição pública, mas demonstram também que elas não estiveram ausentes dos conflitos judiciais. Aparentemente, houve mesmo alguma expansão de sua presença nos autos no século XIX. As mulheres procuravam utilizar os espaços jurídicos como locais de reivindicação e resolução de problemas e conflitos entre vizinhos e parentes. Ainda mais significativo é o fato de que a participação das mulheres entre os notificados alcança números mais expressivos, equivalendo a 20,5\% do total.

Tais dados fazem sentido quando se recorda que a partir da metade do século XVIII a presença feminina e a estruturação familiar se acentuaram. Náo é de estranhar, pois, que, em autos voltados preferencialemente ao encaminhamento de problemas de herança, a presença das mulheres seja bastante relevante. Afinal, cabiam a muitas delas, na condição de mães e viúvas, a administração de bens e a criação de filhos menores. Dessa maneira, se os dados sugerem que as notificaçôes abarcavam fundamentalmente livres e brancos, sugerem também algum peso das mulheres na posse da propriedade privada.

Em linhas gerais, as informaçôes referentes aos usos sociais das notificaçôes fornecem pistas importantes sobre o perfil dos indivíduos nelas envolvidos: proprietários de bens, comumente sediados na cidade ou em seus arredores. O auto de notificação, nesse sentido, foi utilizado como meio através do qual se procurava salvaguardar o acesso e a posse de terras e bens herdados. Os campos diretamente vinculados ao perfil dos envolvidos tendem a corroborar essa hipótese, apesar de se mostrarem decepcionantes em alguns aspectos.

\section{Usos da justiça}

$\mathrm{Na}$ análise das notificaçôes, a pesquisa no AHCS valeu-se de um catálogo antigo escrito à mão, do qual consta, além dos nomes de notificante e notificado, a atribuição a cada auto de um título com vista a resumir seu conteúdo. Sua sistematização permite que se perceba claramente que tipo de uso os habitantes do termo de Mariana faziam dos meios jurídicos oferecidos pelas notificaçóes. A quantificação das entradas do catálogo reforça a ideia de que, embora se prestassem ao tratamento de assuntos variados, as notificaçôes foram associadas, por ordem decrescente, a três tipos gerais de demandas: as que se referiam a testamentos, inventários, heranças e tutelas; as que abrangiam conflitos de propriedade; e as que diziam respeito a transaçóes e créditos. Da totalidade de 783 autos, como indica a tabela 3, os mencionados tipos abarcaram respectivamente 336 (42,9\%), 143 (18,3\%) e 62 (7,9\%) casos — números que atigem $69,2 \%$ do conjunto, mas de todo modo subestimados, uma vez que a investigaçáo verticalizada dos autos restantes certamente os majoraria.

Tabela 3

Tipos gerais de demandas das notificaçóes (1711-1888)

\begin{tabular}{|l|c|}
\hline \multicolumn{1}{|c|}{ Tipos gerais de demanda } & $\%$ \\
\hline Testamentos, inventários, heranças e tutelas & 42,9 \\
\hline Conflitos de propriedade & 18,3 \\
\hline Transaçoes e créditos & 7,9 \\
\hline Total parcial & 69,2 \\
\hline Outros & 30,8 \\
\hline Total & 100,0 \\
\hline
\end{tabular}

Fonte: Notificaçôes (1711-1888); Catálogo das notificações, AHCS. 
A incidência desses temas indica que indivíduos pertencentes às camadas intermediárias tiveram papel importante no uso das notificaçôes. ${ }^{25}$ Tal preponderância pode ser distinguida nos conflitos derivados de créditos e dívidas, o que pode ser ilustrado pela petição seguinte:

Diz Francisco de Aguiar Lima e companheira que, além do que lhe deve por um crédito e fora dele Simão Peixoto de Magalháes, preso na cadeia desta dita [vila] a requerimento do suplicante, por náo dar segurança à importância do dito crédito, está [adstrito], na forma de sua obrigação e rol que junto oferece, dar contas o suplicado [da parte] que tem cobrado das 1392 oitavas e [ilegível] vinténs de ouro a que se obrigou, e o [quanto] ainda devem as pessoas declaradas no dito rol; e para efeito de dar as ditas contas no termo de oito dias, a que se lhe assinarão na primeira audiência de Vossa Mercê, o pretende fazer notificar com a cominação de que, nấo as oferecendo em juízo no dito termo, sustar pelas que o suplicante apresentar em sua contumácia. ${ }^{26}$

As questôes de dívida, no fundo, compunham um tipo geral de demanda cujo cerne estava na disputa pela propriedade. Quando associadas aos casos envolvendo bens de órfãos e contas de inventários e testamentarias, circunscrevem o campo decisivo do embate em torno da transmissão e da manutenção da riqueza. Conflitos envolvendo despejos de casa e terrenos, limites de propriedades, conclusão, embargos e demoliçôes de obras, e cartas de alforria, apesar de suas especificidades, não se excluem de tal circunscrição.

Destaque-se, no entanto, que boa parte de embates dessa natureza, principalmente no século XIX, abarca áreas mais rurais e distantes do termo de Mariana, expressando, assim, a dinâmica da economia mineira após o declínio da mineração. A invasão de pequenas propriedades de plantaçôes por animais é um exemplo disso. Mas tão importante quanto a constatação da existência de diversos autos concernentes às atividades agropastoris e de subsistência é o fato de que alguns deles remetem ao sul do termo e à regiáo da Zona da Mata. As estruturas agrárias desempenharam um papel peculiar na ocupação de tais fronteiras, acarretando o surgimento de pequenas e médias propriedades nessas regiôes. A justiça, por vezes, foi acionada para solucionar impasses resultantes da delimitaçáo imprecisa das propriedades. Uma petição desse tipo, embora relativa à região mais próxima da sede, expressa o problema:

Diz João Francisco Pereira, morador no Brumado, do juízo desta vila, que ele é senhor e possuidor de uma roça sita na mesma paragem [ilegível] na qual planta, há tempo de doze anos, mantimentos e tudo o mais que se lhe oferece; e nela tinha no presente ano plantado dois alqueires e meio de milho; e como Sebastiāo Álvares Caldas, morador na mesma paragem de [ilegível] acima, com o seu gado vacum, que traz sem pastor algum, lhe tem destruído não somente o milho que tinha plantado, mas também bananal e outras mais plantas e outrossim, conforme o [direito], está obrigado o suplicado a ressarcir o dano que o seu gado der (...) por cuja razão o quer fazer citar (.....27

O problema da dinâmica fundiária deve ser, todavia, analisado com cautela. A expansão territorial verificada desde o início da colonizaçáo na regiáo da Vila de Nossa Senhora do Carmo explica a ocor-

\footnotetext{
${ }^{25} \mathrm{O}$ termo "camadas intermediárias" é genérico e, por isso mesmo, insuficiente. No entanto, é utilizado neste artigo para designar grupos e indivíduos que tinham acesso a formas de propriedade, fossem terras ou escravos, distinguindo-se, por um lado, dos setores efetivamente abastados e, por outro, daqueles desprovidos de bens. Embora seja difícil circunscrever empiricamente, através das notificaçóes, os limites das "camadas intermediárias", a recorrência com que os autos se referem a testamentos, inventários e dívidas sinaliza a atuação neles de pequenos e médios proprietários.

${ }^{26}$ AHCS, 2o ofício, códice 178, auto 4.414, ano 1743, fl. 3. Optou-se por atualizar a grafia e a pontuação dos documentos citados.

${ }^{27}$ AHCS, 2o ofício, códice 171, auto 4.158, ano 1730 .
} 
rência de autos cujos contendores não habitavam seu principal núcleo urbano. Porém, as notificaçôes sugerem que o acesso às formas jurídicas esteve condicionado à maior ou menor proximidade em relação à cabeça do termo. A tabela 4, forjada segundo os dados referentes ao local de citação, demonstra claramente o efeito da expansão territorial. A escolha desse aspecto para a análise da distribuição espacial das notificaçóes tem a ver com os procedimentos que norteavam o uso dos autos. Quando não era o próprio Juízo que dava início ao processo, este se originava de petição feita por um determinado requerente. $\mathrm{O}$ despacho do juiz, então, acarretava a citação da parte, como já foi apresentado. Embora determinadas circunstâncias fizessem com que, por vezes, o oficial responsável citasse o notificado na própria cidade, era comum que isso ocorresse no lugar de sua morada. A citação, portanto, oferece um bom termômetro para a investigação do local da contenda.

\section{Tabela 4}

Distribuição espacial das notificaçóes (1711-1888) em \%

\begin{tabular}{|c|c|c|c|c|}
\hline $\mathrm{P} / \mathrm{L}$ & Mariana & Termo & N/C & Relação \\
\hline $1711-1750$ & 50,7 & 26,7 & 22,6 & 1,9 \\
\hline $1751-1808$ & 41,7 & 38,2 & 20,1 & 1,1 \\
\hline $1809-1830$ & 30,3 & 35,8 & 33,9 & 0,8 \\
\hline $1831-1850$ & 35,7 & 30,9 & 33,4 & 1,1 \\
\hline $1851-1888$ & 30,0 & 27,5 & 42,5 & 1,1 \\
\hline $1711-1888$ & 32,0 & 40,1 & 27,9 & 1,1 \\
\hline
\end{tabular}

Fonte: Notificações (1711-1888), AHCS.

P: Período; L: Localização

Quando se comparam as linhas dos períodos 1711-1750 e 1751-1808, nas quais são achados índices parecidos de ausência de informaçóes (22,6\% e 20,1\%), observa-se o traçado de curvas opostas: de declínio para a cidade, de ascensão para o termo. A partir de 1809, o equilíbrio no número de casos de cidade e termo mantém-se, apesar de algumas oscilaçôes. Entretanto, quando se lembra que a ocupação de novas áreas se deu de modo mais ou menos constante durante os séculos XVIII e XIX, esse equilíbrio pode ser apenas aparente. Se a decadência da mineração provocou uma migraçáo interna, principalmente de homens jovens e maduros, no sentido das áreas rurais, a equivalência dos índices (41,7\% e $38,2 \%$ em $1711-1750 ; 30,3 \%$ e $35,8 \%$ em $1809-1830)$ tende a expressar, na verdade, menos possibilidades de acesso a formas jurídicas nas regióes mais afastadas da Cidade Mariana. O aumento do índice de ausência de informaçôes no período 1809-1888 (33,9\%, 33,4\% e 42,5\%) é algo difícil de explicar, podendo advir, por exemplo, de falhas arbitrárias de registro. Mas se for válido o argumento de que quanto maior a proximidade e a familiaridade em relaçáo à sede do termo, menor a preocupaçáo do oficial com o registro, a hipótese indicada acima ganha ainda mais força.

Os litígios pela disputa de bens tornaram-se mais intensos no século XIX, principalmente os que se referiam a contas de inventários, testamentarias e tutorias de menores. Os tutores eram intimados a dar conta dos rendimentos e das despesas da herança dos órfãos menores. Os números sofrem alguma distorçáo resultante dos dados relativos aos anos de 1819 e 1820, período em que Agostinho Marques Perdigão Malheiros, pai do famoso abolicionista, entregou-se, por questóes ainda desconhecidas, à tarefa de encaminhar uma centena de casos atinentes a heranças e tutelas. Um exemplo disso aparece na seguinte petiçáo:

Diz Rosa Maria da Silva, tutora dos órfāos seus filhos legítimos, herdeiros do ajudante Manuel Álvares de Sousa, que foi citada para dar contas do rendimento e despesa respectiva, a qual apresenta e requer a Vossa 
Senhoria se digne mandar que junto aos autos sigam os termos do estilo, copiada a procuraçấo, e sendo [assim] se tome termo [ilegível] nos procuradores que se designar. ${ }^{28}$

Os requerimentos que deram origem às notificaçôes são, nesse sentido, instrumentos bastante pertinentes para a recuperação da dinâmica patrimonial. Uma das lacunas ainda não exploradas devidamente pela historiografia refere-se ao entendimento da complexa atividade que regulava, através de expedientes costumeiros e jurídicos, a transmissão vertical e horizontal de bens.

Dizem Matias Correia Dias e Domingos José de Lima, por cabeça de sua mulher Ana Maria Doroteia, filhos e herdeiros de Alexandre Roiz de Oliveira e sua mulher Ana Cardoso da Fonseca, que, sendo falecidos seus pais há anos bastantes e ficando na posse de todos os bens seu irmão e cunhado Ângelo Inocêncio Roiz, nascidos no Arraial de S. Caetano, não tem o mesmo até o presente inventariado os bens do casal, querendo somente desfrutá-los: por cuja causa querem os Suplicantes fazer citar ao Suplicado para no termo de oito dias, a pena de sequestro e ser lançado do inventário, e ainda de prisão, dar a inventário todos os bens hereditários que ficaram pelos falecimentos dos pais comuns. ${ }^{29}$

A multiplicidade das regras de direito e dos acertos comunitários que procuravam circunscrever os patrimônios foi responsável por situaçôes muitas vezes bastante tensas e confusas. De modo geral, é possível dizer que vigorava nas Minas, principalmente no século XVIII, um fenômeno que pode ser caracterizado como "sobreposição possessória", isto é, um quadro patrimonial em que as intrincadas disputas de bens entre indivíduos, grupos ou geraçóes tornavam difícil estabelecer com certeza a quem pertencia determinada propriedade privada. ${ }^{30}$ Para além das complexidades atinentes ao direito e ao costume, esse fenômeno derivou em grande medida de certa precariedade material. Muito embora as atividades de mercado e os padróes de consumo tenham alcançado êxito em Minas Gerais, os róis de bens listados em inventários e testamentos indicam a pobreza de muitos dos moradores e a rusticidade da vida material.

\section{Juízos e julgadores}

Em relação à atuação dos julgadores, os dados refletem as mudanças ocorridas nas estruturas jurídico-administrativas na primeira metade do século XIX. Trata-se, portanto, de um importante instrumento para avaliar as implicaçóes, flutuaçóes, mudanças e continuidades do gerenciamento da Justiça em Minas Gerais ao longo do período em questáo. Outrossim, os dados sobre os julgadores permitem conhecer os níveis de formação dos mesmos, bem como a maior ou menor presença de uma justiça letrada em Mariana.

Em todo o período analisado, como mostra a tabela 5, a maior parte dos trâmites foi conduzida pelo juiz de fora, responsável, quando somadas as rubricas correspondentes (juiz de fora, juiz de fora e de órfăos, e juiz de fora e provedor dos defuntos e ausentes), por $72,8 \%$ dos autos iniciados por titulares (297 casos entre 408) e por 37,9\% do total geral (297 entre 783). ${ }^{31}$ Esses resultados, contudo, embutem uma deformação, pois sabe-se que as mudanças efetuadas nas décadas de 1820 e 1830, em especial

\footnotetext{
${ }^{28}$ AHCS, $2^{\circ}$ ofício, códice 175 , auto 4.290, ano 1819, fl. 4.

${ }^{29}$ Arquivo Histórico da Casa Setecentista (AHCS), 20 ofício, códice 174, auto 4255, ano 1825.

${ }^{30}$ Sobre as "sobreposições possessórias", ver SILVEIRA, Marco Antonio. Fama pública. Tese (Doutorado em História) Universidade de São Paulo, São Paulo, 2000, em particular o cap. "Os bens da viúva: patrimônio, troca e magia”.

${ }^{31}$ Sobre os juízes de fora de Mariana, ver SOUZA, Débora Cazelato. Administração e poder local: a Câmara de Mariana e seus juízes de fora (1730-1777). Dissertação (mestrado em história) — Universidade Federal de Ouro Preto, Mariana, 2011.
} 
Tabela 5

Função dos julgadores (1711-1888)

\begin{tabular}{|c|c|c|}
\hline \multicolumn{3}{|l|}{ Julgadores } \\
\hline Juiz das justificaçóes, casamentos e resíduos & 1 & \\
\hline Juiz de fora & 164 & \\
\hline Juiz de fora e de órfãos & 131 & \\
\hline Juiz de fora e provedor dos defuntos ausentes & 2 & \\
\hline Juiz de órfãos & 11 & \\
\hline Juiz de paz & 2 & \\
\hline Juiz municipal & 12 & \\
\hline Juiz municipal e órfãos & 26 & \\
\hline Juiz municipal e orfãos da provedoria & 1 & \\
\hline Juiz municipal, de órfãos e provedor das capelas & 1 & \\
\hline Juiz ordinário & 18 & \\
\hline Promotor do juízo & 1 & \\
\hline Provedor & 1 & \\
\hline Provedor dos defuntos e ausentes & 20 & \\
\hline Provedor dos defuntos, ausentes, capelas e resíduos & 15 & \\
\hline Total & 408 & $52,1 \%$ \\
\hline Por comissão* & 248 & $31,7 \%$ \\
\hline Pela ordenação** & 83 & $10,6 \%$ \\
\hline Substituto/suplente/interino*** & 14 & $1,8 \%$ \\
\hline $\mathrm{N} / \mathrm{C}^{* * * *}$ & 28 & $3,6 \%$ \\
\hline Não identificado & 2 & $0,2 \%$ \\
\hline Total geral & 783 & $100,0 \%$ \\
\hline
\end{tabular}

Fonte: Notificações (1711-1888), AHCS.

*Rubricas da categoria "Por Comissão": advogado, advogado de comissão, advogado dos auditórios, advogado nos auditórios e juiz pela Ordenação, comissário, juiz comissionado, juiz de comissão, julgador de comissão.

**Rubricas da categoria "Pela Ordenação": juiz de fora e órfãos pela Ordenação, juiz de fora pela Ordenação, juiz de órfãos pela Ordenação, juiz pela Ordenação, juiz pela Ordenação e de órfãos, vereador mais velho e juiz pela Ordenação.

***Rubricas da categoria "Substituto/suplente/interino": juiz municipal e provedor suplente em exercício; juiz municipal suplente; juiz municipal, de órfaos e provedor suplente; primeiro substituto do juiz municipal e órfaos; primeiro suplente do juiz municipal; provedor interino dos defuntos e ausentes; segundo substituto do juiz de órfaos; segundo substituto do juiz municipal de órfãos; segundo substituto do juiz municipal e órfãos; segundo vereador e mais velho juiz pela Ordenação; substituto do juiz municipal (oficial da Ordem da Rosa).

****Não consta.

as do Código do Processo Criminal, de 1832, não só retiraram das câmaras municipais suas funçôes judiciais, como também extinguiram o posto de juiz de fora. Assim, a alta porcentagem concernente aos julgadores forâneos do século XIX deriva de certa concentraçáo do conjunto dos autos oitocentistas, grosso modo, nos anos de 1810 a 1830. De fato, como se viu acima, o longo período que abrange as décadas de 1830 a 1880 corresponde a apenas um décimo do total dos autos.

Os 4,4\% de juízes ordinários que atuaram em notificaçóes iniciadas por titulates (18 entre 408) remetem à fase anterior a 1730, quando foi estabelecido um juiz de fora em Mariana. Quando às porcentagens de juiz ordinário e de juiz de fora são acrescidas as do juiz municipal em suas várias rubricas (juiz municipal; juiz municipal e órfăos; juiz municipal e órfãos da Provedoria; juiz municipal, de ór- 
fấos e provedor das capelas), cargo que incorporou suas funçôes e atingiu 9,8\% do total (40 entre 408), percebe-se que as notificaçôes foram instrumentos utilizados preferencialmente na primeira instância judicial. Essa hipótese é corroborada pela constatação de que os diversos tipos de julgadores aptos a substituir os titulares assinalados — comissionados, advogados e juízes pela Ordenação — alcançam, juntos, cifras também significativas. A distribuição dos autos pelos juízos em que tramitaram ajuda a entender melhor os dados da tabela 6 .

Tabela 6

Distribuiçáo nas notificaçóes por instância julgadora em \% (1711-1888)

\begin{tabular}{|c|c|c|c|c|c|}
\hline P/I & Ordinário & Órfãos & Provedoria & Outros & NC \\
\hline $1711-1750$ & 77,3 & 20,0 & 1,3 & --- & 0,7 \\
\hline $1751-1808$ & 62,2 & 15,0 & 22,4 & 0,4 & --- \\
\hline $1809-1830$ & 44,8 & 36,5 & 18,7 & --- & --- \\
\hline $1831-1850$ & 42,9 & 40,5 & 9,5 & 7,1 & --- \\
\hline $1851-1888$ & 10,0 & 22,5 & 57,5 & 10,0 & -- \\
\hline $1711-1888$ & 54,3 & 26,4 & 18,1 & 1,0 & 0,9 \\
\hline
\end{tabular}

Fonte: Notificações (1711-1888), AHCS.

P: Período; I: Instância julgadora

Quando cotejadas as tabelas 5 e 6, são expressivas as diferenças entre os índices de juízes de órfãos e Juízo de Órfãos, entre juízes ordinários e Juízo Ordinário, bem como entre provedores e Provedoria dos Defuntos e Ausentes, com ampla vantagem para os três últimos itens de comparação. No que concerne à jurisdição ordinária, a distorção é parcialmente explicada pelo peso de julgadores por comissão ou Ordenação. A esse ponto deve ser acrescido que os juízes de fora, como presidentes das câmaras municipais, atuavam oficialmente na circunscrição ordinária. Em outras palavras, os autos tramitados no Juízo Ordinário foram conduzidos por diferentes tipos de julgadores: juízes ordinários (até a década de 1730), juízes de fora, juízes municipais (desde a década de 1830), juízes pela Ordenação e comissionados. No que diz respeito ao Juízo de Órfãos, basta lembrar que suas funçôes eram acumuladas pelos julgadores forâneos. O mesmo ocorria em relação à Provedoria.

Outro aspecto importante sobre o perfil dos julgadores refere-se à sua qualificação por meio de títulos e patentes. Informes dessa natureza permitem que se definam melhor os grupos sociais em que estavam inseridos os juízes.

Como pode ser observado acima, as categorias de desembargador e doutor, juntas, atingem $74,8 \%$, havendo ampla preponderância dos primeiros. Esse dado coaduna-se com o da tabela 6 na medida em que os principais julgadores, sendo juízes de fora ou advogados comissionados, tinham de ostentar pelo menos a titulaçáo de doutor em direito. A forte presença de juízes diplomados nos autos sugere que parte expressiva de feitos e instrumentos judiciais fora encaminhada por magistrados conhecedores das leis, e não por leigos. É preciso, contudo, observar que tal aspecto, por si só, não era garantia de um exercício mais eficiente da justiça, já que muitos dos autos podiam ser atravessados pelas relaçôes clientelistas ou perderem-se por falta de despacho. A presença de julgadores com formaçáo acadêmica em circunscriçôes tão vastas, ocupados ainda em funções diversas, compõe o quadro ambíguo do exercício da justiça em Minas.

Em 18,6\% dos casos, os juízes eram leigos e portavam patente militar. O peso dos capitáes nesse conjunto, correspondente à metade do total, não é de se estranhar visto que os juízes ordinários elegiam-se entre os homens bons, de cuja caracterização fazia parte a ostentação de boas patentes. 
Tabela 7

Títulos e patentes dos julgadores dos autos de notificaçáo (termo de Mariana, 1711-1888)

\begin{tabular}{|l|c|}
\hline Título ou patente & $\%$ \\
\hline Doutor & 60,7 \\
\hline Desembargador & 14,1 \\
\hline Advogado & 1,1 \\
\hline Capitão & 9,2 \\
\hline Coronel & 2,4 \\
\hline Sargento & 4,3 \\
\hline Tenente & 2,0 \\
\hline Alferes & 0,7 \\
\hline Cirurgião-mor & 0,7 \\
\hline Outros & 0,8 \\
\hline NC* & 4,0 \\
\hline Total & 100,0 \\
\hline
\end{tabular}

* Não consta.

Fonte: AHCS.

Além disso, entre os juízes por ordenação, isto é, os vereadores mais velhos a quem cabia substituir os ordinários na sua ausência, valia o mesmo princípio. Há de se ressaltar, por essas mesmas razóes, que a situação de Mariana era decerto específica na capitania de Minas Gerais em decorrência da presença do juiz de fora já na década de 1730. Provavelmente, nas demais câmaras mineiras, onde vigoraram os juízes ordinários por todo o século XVIII — sendo Campanha, no sul de Minas Gerais, uma exceçáo tardia -, o número de juízes letrados tenha sido menor. De uma maneira ou de outra, os trâmites nos tribunais dependeram do convívio próximo entre julgadores leigos e formados, até porque muitos destes eram indicados por aqueles para substituí-los em audiências. ${ }^{32}$ Uma análise mais pormenorizada dos autos de notificação demonstra como o mesmo instrumento passava, nas diversas audiências, pelas mãos de juízes diferentes, havendo, às vezes, um número grande de julgadores atuando num mesmo auto ou processo. Uma vez que parte dos doutores apontados na tabela 7 eram advogados comissionados, uma questáo crucial consiste em saber que tipo de relação se mantinha entre os juízes letrados e os principais escritórios de advogados locais. ${ }^{33}$

Outro aspecto importante ainda por elucidar diz respeito ao oficial de citação, um agente decisivo para o exercício cotidiano da justiça. Era ele quem estabelecia o vínculo entre o juízo e o notificando ao intimá-lo a comparecer nas audiências definidas. Que a atuaçáo desses e outros oficiais estava longe de ser neutra mostram as referências esparsas relativas à cobrança de peitas junto aos interessados. O esboço do perfil dos oficiais de citação da Mariana dos séculos XVIII e XIX auxiliaria no entendimento da articulação de instâncias variadas de caráter policial e judicial, bem como permitiria que se avaliasse se e como os instrumentos legais chegavam às partes mais distantes e recônditas do termo.

\footnotetext{
${ }^{32}$ Carmem Silvia Lemos apurou que, num total de 122 devassas, 82 (67,20\%) foram procedidas por juízes ordinários não letrados, mas somente dez deles, ou seja, 8,19\%, não fizeram uso explícito de um assessor letrado. LEMOS, Carmem Silvia. A justiça local: os juízes ordinários e as devassas da Comarca de Vila Rica (1750-1808), op. cit. p. 68-71.

${ }^{33}$ ANTUNES, Álvaro de Araújo. Fiat justitia: os advogados e a prática da justiça em Minas Gerais (1750-1808). Tese (doutorado em história) — Universidade Estadual de Campinas, Campinas, 2005.
} 


\section{Tabela 8}

Funçáo dos oficiais de citaçáo (termo de Mariana, 1711-1888)

\begin{tabular}{|l|c|}
\hline Função & $\%$ \\
\hline Escrivão & 31,1 \\
\hline Tabelião & 4,5 \\
\hline Alcaide & 3,5 \\
\hline Meirinho & 5,2 \\
\hline Oficial de justiça & 2,0 \\
\hline Juiz de paz & 0,1 \\
\hline Juiz de vintena & 9,0 \\
\hline Juiz de fora & 0,1 \\
\hline Padre & 0,1 \\
\hline NC* & 44,4 \\
\hline Total & 100,0 \\
\hline
\end{tabular}

* Não consta.

Fonte: AHCS.

A quantidade expressiva de casos para os quais não há informação disponível deve-se geralmente ao fato de o oficial assinar o nome, mas não indicar seu ofício. Somente uma investigação mais cuidadosa permitiria sanar em parte essa deficiência. Entre os dados conhecidos, chamam a atenção não apenas o destaque alcançado pelo escrivão, mas também a constatação de que, quando a porcentagem de suas citaçóes é somada à de tabeliáo e alcaide, chega-se a 39,1\% do total. Tais informes propóem que parte significativa das citaçôes era feita nas próprias dependências do tribunal ou em suas cercanias. $O$ único oficial exclusivamente relacionado aos distritos e arraiais, o juiz de vintena, atinge apenas a quantia de $9,0 \%$. Como se viu antes, havia significativa tendência de encaminhamento de autos relativos à cidade em detrimento daqueles relativos ao termo É o que sugere também a tabela 9.

Tabela 9

Local de citaçáo (termo de Mariana, 1711-1888)

\begin{tabular}{|l|r|}
\hline Função & $\%$ \\
\hline Mariana & 72,9 \\
\hline Sáo Caetano & 5,1 \\
\hline Furquim & 4,2 \\
\hline Bento Rodrigues & 1,9 \\
\hline Antônio Pereira & 1,6 \\
\hline Sumidouro & 1,9 \\
\hline Brumado & 1,1 \\
\hline Catas Altas & 4,6 \\
\hline Inficionado & 2,8 \\
\hline Bacalhau & 1,6 \\
\hline Chopotó & 2,3 \\
\hline Total & 100,0 \\
\hline
\end{tabular}

Fonte: AHCS. 
Em 72,9\% dos casos, as citações foram realizadas na própria Cidade Mariana. Se esse número é acrescido dos relativos às localidades mais próximas da sede do termo, torna-se patente que a distância influenciava de modo decisivo no exercício da justiça. Ainda que se formule uma hipótese distinta - a de que os juízes mandavam citar o notificado por terem notícia de sua vinda à sede - é difícil crer que a distância em relação ao tribunal não produzisse algum tipo de exclusão.

\section{Sentenças e interrupçóes}

Como foi descrito acima, a notificação era um instrumento jurídico através do qual se chamava a juízo uma determinada parte para que efetuasse certo procedimento, muitas vezes táo corriqueiro quanto aceitar uma testamentaria. Por isso, boa quantidade dos autos não previa sentenças. Em algumas ocasióes, quando, por exemplo, o notificado devia apresentar em juízo contas de testamentaria, estas últimas, depois de avaliadas e aceitas, eram julgadas por sentença. Todavia, dúvidas ou recusas referentes à origem da notificação podiam transformá-la em processos de outra natureza, como os libelos cíveis, que se estendiam por muito tempo. Essas observaçôes sobre a natureza das notificaçóes são importantes para que se compreendam os limites dos dados atinentes à existência de sentenças ou à interrupção dos autos. Nos feitos que previam sentenças, o processo, evidentemente, ou era com elas finalizado, ou não. Em outros casos, embora os autos não demandassem sentença, podiam ser finalizados ou permanecer interrompidos por qualquer razão. Havia ainda situaçôes nas quais a interrupção resultava do acordo entre as partes, comumente não registrado nos autos. Por esses motivos, é arriscado estabelecer afirmaçóes categóricas acerca da relação entre a porcentagem de finalização dos autos e a eficácia da Justiça.

Quando são considerados finalizados os autos que apresentam sentenças, seu número alcança pouco mais de um terço do total. Porém, o peso dos feitos inconclusos foi provavelmente menor, pois o critério adotado acaba por ignorar os desfechos informais, bem como o fato de que muitas notificaçóes dispensavam sentenças. Ainda assim, deve-se repetir, os dados indicam falhas no exercício cotidiano da justiça. É bastante crível que parte significativa das queixas da população formuladas junto aos meios jurídicos tenha acabado sem solução ou engavetada. Ressalte-se, contudo, que, em certas ocasióes, os moradores acionavam a Justiça para encaminhar seus impasses, podendo em seguida buscar uma solução através de acordos informais. Nesse sentido, recorrer ao campo jurídico implicaria uma estratégia para intimidar a parte oposta com o intuito de forçá-la a negociar e evitar gastos judiciais.

No montante de autos finalizados, as sentenças poderiam ser favoráveis ao notificante ou ao notificado, geralmente transformados, no caso de desdobramento das notificações em processos efetivos, em autor e réu. Em algumas circunstâncias, ambas as partes ganhavam e perdiam — ou, em outras palavras, tinham suas demandas reconhecidas parcialmente, sendo, mesmo assim, condenadas em algo.

As porcentagens da tabela 10, por sua vez, sugerem que, caso os autos seguissem até os trâmites finais, grande quantidade dos reclamantes alcançava seus objetivos. Embora haja consultas preliminares nesse sentido, seria necessário, porém, avaliar minuciosamente se há alguma relação entre a duração dos feitos e a obtenção de sentenças favoráveis. O cruzamento de ambas as variáveis tenderia, segundo as sondagens iniciais, a mostrar que o alcance da sentença esteve diretamente relacionado à longa duração dos pleitos e, consequentemente, à tendência de que envolvessem indivíduos de posse. Se assim for, os dados das tabelas 10 e 11 reforçariam a hipótese de uma apropriação mais positiva dos instrumentos jurídicos por parte de gente rica ou remediada.

Todavia, essa hipótese também deve ser relativizada quando se verifica, através da tabela 11, que a duração da maioria dos autos não ultrapassou um ano. 
Tabela 10

Sentenças favoráveis a notificantes/autores e notificados/réus (1711-1888)

\begin{tabular}{|c|c|c|r|r|r|r|r|c|}
\hline P/A e R & A & $\%$ & $\mathrm{R}$ & $\%$ & $\mathrm{~A} / \mathrm{R}$ & $\%$ & $\mathrm{~N} / \mathrm{C}$ & $\%$ \\
\hline $1711-1750$ & 36 & 24,5 & 8 & 5,4 & 1 & 0,7 & 102 & 69,3 \\
\hline $1751-1808$ & 35 & 14,0 & 20 & 8,0 & 4 & 1,6 & 191 & 76,4 \\
\hline $1809-1830$ & 74 & 24,3 & 20 & 6,6 & 11 & 3,6 & 199 & 65,5 \\
\hline $1831-1850$ & 5 & 11,9 & 2 & 4,8 & 1 & 2,4 & 34 & 80,9 \\
\hline $1850-1888$ & 6 & 15,0 & 2 & 5,0 & 1 & 0,9 & 31 & 77,5 \\
\hline $1711-1888$ & 154 & 19,5 & 51 & 6,5 & 17 & 2,2 & 561 & 71,6 \\
\hline
\end{tabular}

Fonte: Notificaçóes (1711-1888), AHCS.

P/A e R: Período/Autor e Réu

A: Sentença favorável ao notificante/autor; R: Setença favorável ao notificado/réu; A/R: Sentença favorável ao notificante/autor e ao notificado/réu; N/C: Não consta.

Tabela 11

Porcentagem de notificaçóes distribuídas segundo duraçáo e períodos (1711-1888)

\begin{tabular}{|c|c|c|c|c|c|c|}
\hline Duração/Período & A & B & C & D & E & F \\
\hline Até 5 dias & 18,7 & 18,5 & 13,5 & 28,6 & 5,0 & 16,7 \\
\hline Até 10 dias & 25,3 & 25,6 & 15,5 & 31,0 & 5,0 & 20,9 \\
\hline Até 30 dias & 44,0 & 35,8 & 22,9 & 47,6 & 17,5 & 32,6 \\
\hline Até 60 dias & 59,3 & 48,0 & 34,2 & 54,8 & 32,5 & 44,7 \\
\hline Até 90 dias & 64,7 & 55,9 & 40,6 & 61,9 & 32,5 & 51,1 \\
\hline Até 180 dias & 81,3 & 64,6 & 55,2 & 73,8 & 40,0 & 63,5 \\
\hline Até 1 ano & 90,7 & 76,0 & 71,9 & 83,3 & 62,5 & 77,0 \\
\hline Até 2 anos & 97,3 & 85,4 & 85,5 & 90,5 & 70,0 & 87,1 \\
\hline Ate 3 anos & 99,3 & 90,2 & 88,7 & 95,2 & 77,5 & 90,8 \\
\hline Até 4 anos & 99,3 & 92,5 & 91,6 & 95,2 & 87,5 & 93,2 \\
\hline Até 5 anos & 100,0 & 93,7 & 92,6 & 95,2 & 90,0 & 94,3 \\
\hline Até 10 anos & --- & 97,2 & 98,7 & 100,0 & 97,5 & 98,5 \\
\hline Até 20 anos & --- & 98,8 & 99,7 & --- & 100,0 & 99,5 \\
\hline Até 40 anos & --- & 99,6 & 100,0 & --- & --- & 99,9 \\
\hline
\end{tabular}

Fonte: Notificações (1711-1888), AHCS.

A: 1711-1750; B: 1751-1808; C: 1809-1830; D: 1831-1850; E: 1851-1888; F: 1711-1888.

Em boa medida, a duração relativamente curta dos autos resulta da própria natureza das notificaçóes, voltadas para o encaminhamento de problemas objetivos tais como a apresentaçáo de contas de tutela ou a justificação do levantamento de uma parede ou cerca. Mas esse mesmo fator é um forte indicativo de que, se, por um lado, as notificaçóes desdobravam-se em outros tipos de processo, reproduzindo, dessa maneira, os padróes excludentes da dinâmica judicial dos séculos XVIII e XIX, por outro, elas efetivamente abriam-se à resoluçáo expedita de assuntos de interesse mais amplo, especialmente alguns daqueles relacionados à transmissão da herança e ao controle da propriedade.

Contudo, a tabela 11 ainda informa que, após 90 dias de seu início, praticamente metade das notificaçôes continuava em andamento; o mesmo ocorreu com mais de um terço delas após 180 dias, e com quase um quarto após um ano. Articulando-se as informaçóes das tabelas 10 e 11, talvez seja adequado propor que, descontados os casos de resolução expedita e os que implicaram interrupçôes, as notifica- 
çôes envolveram um número minoritário, mas não desprezível, de contendas cujo desdobramento se estendeu por certo tempo, trazendo, porém, alguma satisfaçáo aos autores.

\section{Conclusóes}

Como indicam os exemplos, as notificaçôes consistem num tipo de fonte que tem a vantagem de expressar toda uma dinâmica social que dificilmente é contemplada por inventários e testamentos. Esse aspecto é marcadamente importante quando se retoma a discussão acima referida sobre o grau de institucionalização da sociedade mineira em face das flutuaçóes conjunturais, de tempo e espaço. Se as petiçôes sugerem que formas de mediação de conflitos foram sendo gestadas no decorrer do tempo através da confecção de costumes ou do recurso à Justiça, mostram também que as Minas eram uma sociedade trespassada pela disputa encarniçada em torno da aquisição e circunscrição da propriedade privada. Dessa maneira, em que pese a contribuição dos estudos que reconstituem a existência de mercados e de camadas intermediárias estabelecidas, somente a investigação minuciosa da dinâmica patrimonial é capaz de fornecer respostas mais criteriosas sobre a efetiva extensão da economia e sobre o que seu funcionamento significava em termos de estabilidade ou luta social. Do mesmo modo, questóes dessa espécie demandam ainda a análise sobre a formação, entre vizinhos e parentes, de uma consciência de privacidade, visto que várias notificaçôes abordam diretamente o problema da preservaçáo da intimidade familiar.

Apesar do estado ainda preliminar do tratamento dos dados, eles permitem adiantar algumas tendências importantes. A existência de recursos jurídicos acessíveis à parte das camadas pobres e remediadas é uma delas. A própria sobrevivência de um grande número de notificaçóes e o fato de envolverem questôes caras aos moradores comuns de Mariana demonstram esse aspecto. A presença de mulheres como notificantes e notificadas, ampliada no século XIX, sugere que o sentimento de justiça não se limitou aos homens. Uma vez que as questôes concernentes aos bens — expressas não apenas na posse de terras e casas, mas ainda nas dívidas, testamentarias, inventários e tutorias — abrangiam também mulheres, sua atuação junto aos tribunais foi se tornando mais importante.

A atuação dos juízes de fora, por sua vez, parece apontar para uma tendência contraditória. Se, por um lado, sua presença no julgamento de mais de um terço dos processos ratifica o peso dos magistrados enviados pela Coroa no exercício da justiça local, a forte atuação de comissionados (sejam doutores, advogados ou patenteados) indica a incapacidade de os julgadores forâneos darem conta do excesso de demandas típico de suas funçôes. Esse último ponto pode representar a fragilidade das instâncias julgadoras, mais abertas à dinâmica clientelista local.

Outro limite aparece na ampla predominância de citaçóes feitas aos moradores da Cidade Mariana, em contraposição àquelas envolvendo os distritos. Tal discrepância, como foi assinalada, certamente relaciona-se não apenas com as diferenças na composição demográfica do termo como um todo, mas também com a variável da proximidade ou distância dos tribunais. Da mesma forma, o número majoritário de processos interrompidos, incrementado no século XIX, tende a corroborar a ideia de que o acesso às instâncias judiciais não implicava necessariamente o acesso à reparação legal. Ainda que parte das interrupçóes possa ser entendida pela existência de acordos entre as partes, esse fator, por si só, não é capaz de explicar o peso das porcentagens alcançadas. Quando se comparam tais fragilidades com o sucesso obtido pela maioria dos notificantes cujos processos foram finalizados, e com certa brevidade no andamento das açôes (em torno de três quartos delas durando um ano ou menos), conclui-se que os tribunais, embora se abrissem para as camadas pobres e remediadas, oferecendo-lhes formas rápidas de reparação, náo eram, todavia, capazes de satisfazer de modo eficiente as demandas sociais delas advindas. Tudo indica que permanecia uma significativa sensação de desamparo. 